\title{
Glasswashing and Sterilization Shared Resource
}

National Cancer Institute

\section{Source}

National Cancer Institute. Glasswashing and Sterilization Shared Resource. NCI

Thesaurus. Code C39414.

The Glasswashing and Sterilization Shared Resource perform the preparation of clean sterile regular and special needs glassware for Cancer Center laboratories. 